\title{
Proportion of knotty wood in stems of 28-year old lodgepole and Scots pine in experimental plantation in Zvirgzde, Latvia
}

\author{
Aris Jansons ${ }^{1}$, Roberts Matisons ${ }^{1} \bowtie$, Agris Pobiarzens $^{2}$, Linards Sisenis $^{3}$, Una Neimane $^{1}$ \\ ${ }^{1}$ Latvian State Forest Research Institute Silava, Rigas 111, Salaspils, LV-2169 Latvia, phone: +371 29789581, \\ e-mail: robism@inbox.lv \\ ${ }^{2}$ Forest Competence Centre Ltd., Dzerbenes 27, Riga, LV-1006 Latvia \\ ${ }^{3}$ Latvia University of Agriculture, Faculty of Forestry, Akademijas 11, Jelgava, LV-3001 Latvia
}

\begin{abstract}
In forestry, alien tree species are planted to maximize yield from a stand by increasing productivity and decreasing environmental risks. In Eastern Europe, lodgepole pine (Pinus contorta var. latifolia) might be used as a source of biomass and industrial wood; however, before any recommendations are given, possible gains of the novel species should be scrupulously evaluated. In this study, we compared volume and proportion of knotty stemwood (VKN) of native Scots pine (Pinus sylvestris) from first generation seed orchards and provenances of alien lodgepole pine [Fort Nelson (58 $\left.38^{\prime} \mathrm{N}, 122^{\circ} 41^{\prime} \mathrm{W}\right)$ and Summit Lake $\left.\left.\left(54^{\circ} 24>\mathrm{N}, 122^{\circ} 37\right\rangle \mathrm{W}\right)\right]$ at the age of 27 years growing in central Latvia. We also assessed the relationships between VKN and several morphometric parameters.

Stem diameter of both species was similar; however, Summit Lake provenance of lodgepole pine exceeded Scots pine in height, while Fort Nelson provenance was lower than Scots pine. Although Scots pine produced nearly two times less whorls than lodgepole pine, volume of knotless stemwood did not differ significantly between the species; though it was higher for Summit Lake provenance of lodgepole pine compared to Scots pine. In contrast, the proportion of VKN differed significantly between both the species and the provenances. Scots pine showed the lowest proportion of VKN $(\sim 9 \%)$ and Fort Nelson provenances of lodgepole pine showed the highest proportion of VKN ( 14\%). Thus, Summit Lake appears more suitable for the production of industrial wood amongst the provenances of lodgepole pine; nevertheless, higher quantity of leftover material is expected. Some morphometric parameters correlated with VKN and the proportion of VKN, but these relationships differed between species and provenances. The total cross-section of branches was the best predictors of VKN for Scots pine and Fort Nelson provenance of lodgepole pine, while stem diameter showed the strongest correlation for Summit Lake provenance. Number of whorls and mean diameter of living branches were the best predictors of the proportion of VKN for lodgepole pine and Scots pine, respectively. Accordingly, morphometric parameters might be useful for the selection of the best trees of lodgepole pine.
\end{abstract}

\section{KEY WORDS}

Pinus contorta, introduced species, stemwood knottiness, industrial timber, branch traits 


\section{INTRODUCTION}

Attempts of introduction of alien species are made to increase yields from the same area of land by gaining higher productivity or lowering risks of natural hazards (Savill et al. 1997; Burton 2012). In northern Europe, one of such alien conifers is lodgepole pine, which is an ecologically plastic species native to Northern America (Pfister and Daubenmire 1975; Wheeler and Critchfield 1985). It is ecologically plastic species that can grow in a variety of forest types at wide range of latitudes (from 30 to $64^{\circ} \mathrm{N}$ lat.) and altitudes (from 0 to 3900 meters ASL) under oceanic and continental climate (Elfving et al. 2001). Lodgepole pine has been introduced in forestry in several countries in Europe (Larsen 1980; Gallagher et al. 1987; Lines 1996), with extensive plantings in Sweden (Elfving et al. 2001). Experiments in Sweden have shown that lodgepole pine outmatches productivity of native Scots pine in similar conditions (Elfving and Norgren 1993; Elfving et al. 2001). In Latvia, lodgepole pine has been introduced in several experimental plantations that occupy $\sim 16$ ha (Baumanis et al. 2006) and high productivity has also been observed (Baumanis et al. 1992). Lodgepole pine is known to be less affected by pests (Lindelöw and Björkman 2001; Žiogas et al. 2006) and it has shorter rotation period and lower mortality in the initial stage of stand, compared with Scots pine (Gallagher et al. 1987; Elfving et al. 2001). However, lodgepole pine has lower wood density (Persson 1993) and is more susceptible to wind and snow damage (Elfving and Norgren 1993). Although Scots pine normally produces one whorl per year (Bialobok 1975), lodgepole pine can form several whorls per season (Koch 1996; Mauriņš and Zvirgzds 2006), thus increasing the knottiness of the wood. Nevertheless, branches are thinner and branch angles are wider compared to Scots pine (Baumanis et al. 1992; Elfving et al. 2001). Considering the knottiness of lodgepole pine, it might be used as energy crop or as source of industrial wood (Whiteman and Brown 1999; Kärkkäinen et al. 2008).

The quality of timber for industrial purposes is influenced by many factors such as density, hardiness, colour, tree ring pattern and knottiness of wood (Shmulsky and Jones 2011) along with diverse fibre parameters (Sable et al. 2012). If jointed boards are considered as the product of interest, knottiness of timber is a crucial parameter, which affects the yields of production, as the knots should be removed from the wood, thus decreasing the volume of expedient wood (Sauter 1997). Volume of wood occupied by knots (VKN) is also affected by the angle of branches, as steeper branches have longer projections on the axis of stem (Burton 2012). In this respect, trees with faster height growth, a lower number of whorls per unit of length and wider branch angles, are preferable. Height growth and branch angle are influenced by genetic factors and stand properties (Cieszewski and Bella 1989; Mäkinen and Colin 1998), whilst height increment is also sensitive to meteorological conditions (Jansons et al. 2013), thus higher yields might be gained by appropriate management and/or selection.

The aim of this study was to compare the amount of knotless stemwood of Scots pine and lodgepole pine growing in Latvia and to relate the proportion of VKN with tree dimensions and branch properties. We hypothesized that the amount of the knotless wood is higher in stems of Scots pine due to lower number of whorls.

\section{Material AND MethodS}

\section{Study area}

The study area was located in the central part of Latvia, near Zvirgzde (56 $41 \mathrm{~N}$ lat., $24^{\circ} 27 \mathrm{E}$ long.) (Fig. 1). The relief in the study area is flat; elevation is about 30 metres ASL. According to data from the Latvian Environment, Geology and Meteorology Centre (LEGMC) mean annual temperature is $\sim+5.5^{\circ} \mathrm{C}$ with January being the coldest month (mean temperature is $\sim-5^{\circ} \mathrm{C}$ ) and July being the warmest (mean temperature is $\sim+17^{\circ} \mathrm{C}$ ). Annual precipitation ranges from 500 to $650 \mathrm{~mm}$, with most falling during summer, and the amount of rain during the growing period varying from 203 to $412 \mathrm{~mm}$. The length of the vegetation period (mean diurnal temperature $>+5^{\circ} \mathrm{C}$ ) is $\sim 185-190$ days.

Adjacent provenance trials of lodgepole pine and Scots pine, planted in 1985 by two-years old barerooted seedlings in Vacciniosa forest type [according to classification by Bušs (1976)], were sampled. Initial spacing of trees in both trails was $2 \times 1 \mathrm{~m}(5000$ trees per ha) and no thinning was conducted prior to the sampling. The trial consisted of two provenances of 
lodgepole pine, Fort Nelson (58 $\left.38>\mathrm{N}, 122^{\circ} 41>\mathrm{W}\right)$ and Summit Lake $\left(54^{\circ} 24>\mathrm{N}, 122^{\circ} 37\right.$ > W), each represented by 5 open-pollinated families, planted in 60 tree block plots and randomly distributed in 4 replications, and open-pollinated progenies of local Scots pine (control) from the first generation seed orchards, planted in 50 or 100 tree block-plots and randomly distributed in 5 replications.

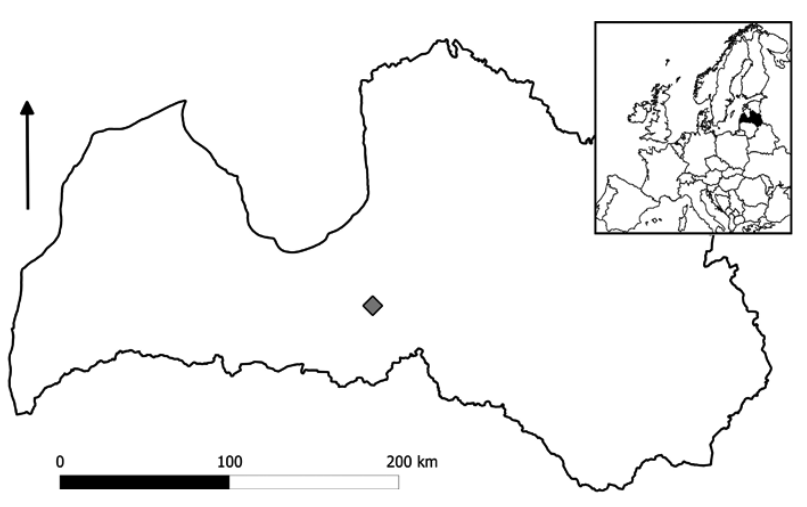

Figure 1. Location of study area (grey square) $\left(56^{\circ} 38^{\prime} 34^{\prime \prime} \mathrm{N}\right.$, $\left.24^{\circ} 28^{\prime} 10^{\prime \prime} \mathrm{E}\right)$

\section{Sampling}

Trees were sampled in January-March 2010; in total, 44 living lodgepole pine and 42 Scots pine trees, representing height and diameter distribution of the plantation, were selected based on the trial inventory. The selected trees were felled; cutting was done maximally close to stem base. Height of an arbitrarily determined middle-point of each whorl (branches were not the same diameter and not at the same height) was measured with precision to the nearest centimetre. For each whorl, number of branches was counted and diameter of living and dry branches was measured with the precision to the nearest millimetre. Branch diameter was measured parallel to the stem axis, thus capturing projected diameter of branches. Branch parameters were not measured for several trees sampled in February 2010. For accurate estimation of changes in stem diameter along the stem axis (taper), four centimetre thick stem discs were taken at the one-metre mark along the stem from the base. In the laboratory, stem discs were dried and their diameter in three directions (without bark) was measured by calliper with accuracy of $0.1 \mathrm{~cm}$. In 2013, branch angle for 16 Scots pine and 16 lodgepole pine trees from the same trial representing the same groups were measured using a protractor. For each tree, angles of four branches from three whorls from each quarter of the living part of the crown (living branches present) and lower part of stem (only dry branches present) were determined.

\section{Data analysis}

For the description of changes in stem diameter along the stem axis, linear models were empirically fitted to mean diameter data of each tree, using height of the obtained stem discs as the independent variable. Stem diameter for each tree at each whorl was determined according to the fitted models, which overall showed good fit to the data $\left(\mathrm{R}^{2}>0.94\right)$. The length of stem in each whorl occupied by branches (projection of height of branch in wood on axis of stem) was calculated as $\mathrm{h}=0.5 \mathrm{~d} \operatorname{ctg} \alpha$, where $d$-diameter of stem at height of the whorl, $\alpha$-mean angle of the branch in the relevant quarter of stem. VKN was then calculated as volume of truncated cone, $\mathrm{V}=\pi \mathrm{h}\left(\mathrm{R}^{2}+\mathrm{Rr}+\mathrm{r}^{2}\right) / 3$, where $R$ - lower base radius, $r$ - upper base radius (upper and lower base radii were calculated based on fitted models diameter-height models, considering $h$ ). Similarly the volume of knotless wood was estimated and the proportion of VKN was assessed for whole tree and additionally for separate quarters of the crown (part of stem where living branches were present) and for the lowest part of stem (where only dry branches were present).

Similarity of trees according to branch parameters [number of branches and whorls, mean distance between whorls, mean and maximum diameter and their sum of squares of branches (living and dry)] and volumes of wood with and without branches (knots) was assessed by PCA (Principal Component Analysis) based on the correlation matrix. The significance of principal components (scores of trees) was determined by the randomization tests performing 10000 iterations. The differences in diameter, height, stem volume and branch parameters between provenances of lodgepole pine and Scots pine was assessed by ANOVA and Tukey's HSD test (Sokal and Rohlf 1995). For each parameter and group, normality was assessed graphically by the Q-Q plot. Homogeneity of variance was assessed by the Levene's test. The relationships between wood volume and branch parameters were assessed using Pearson correla- 
tion analysis. Data analysis was conducted in program R v. 3.0.1. (R Core Team 2014) using library "vegan" (Oksanen et al. 2013).

\section{Results}

Diameter of the sampled trees did not differ significantly between species or provenances of lodgepole pine; however, the differences in height of trees were significant $(p$-value $<0.05)$ (Fig. 2). Scots pine showed intermediate height, while provenances of lodgepole pine were the highest (Summit Lake) and the lowest (Fort Nelson) amongst the sampled trees. For both species, branch angles were rather similar and a decrease of branch angles from the lowest part of the stem (dry branch zone) upwards (fourth quarter of crown) was observed (Fig. 3). Although the branch angles overall were quite similar between Scots pine and lodgepole pine, lodgepole pine showed significantly higher angle of dry branches in the

A

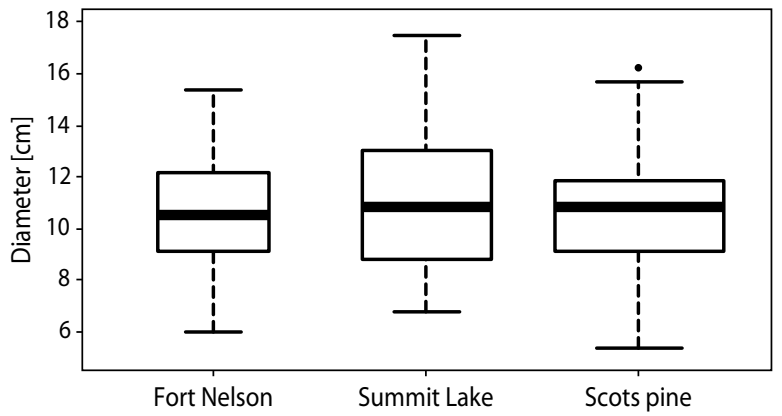

B

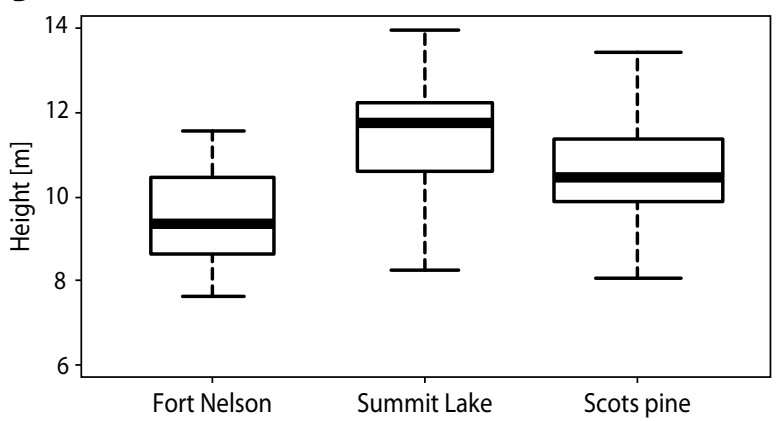

Figure 2. Mean diameter (A) and height (B) of sampled trees of Fort Nelson and Summit Lake provenances of lodgepole pine and Scots pine. Width of boxes represent number of sampled trees lower part of stem and similarly, slightly higher angles of living branches.

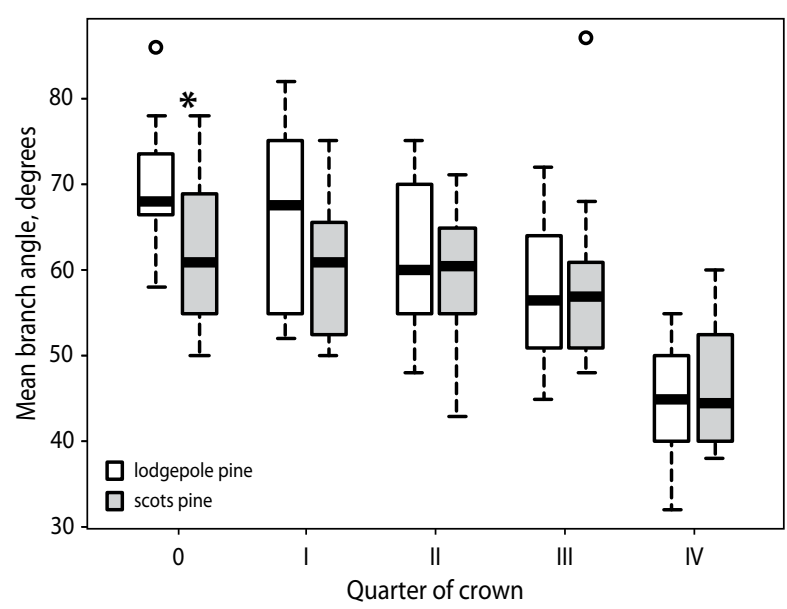

Figure 3. Branch angle of Scots pine and lodgepole pine in four quarters of crown (I-IV) and dry branch part of stem (0). Asterisks indicate significant differences ( $p$-value $<0.05)$

Principal Component Analysis based on parameters of the trees (VKN, knotless wood volume, number of whorls and diameter, number and cross-section area of branches) showed that the first two principal components (scores of PC I and PC II) for trees were significant ( $p$-value $<0.01$ ) and explained the 51 and $27 \%$ of data variation, respectively. Grouping of trees according to species could be easily identified (Fig. 4), suggesting differences in branch traits; however, lodgepole pine trees showed neither distinct grouping nor gradient according to provenance (formed common group). Scores of the PC I of trees showed the strongest correlation with the VKN $(|r|=0.95)$ and scores of PC II had the strongest correlation with number of whorls $(|r|=0.84)$, suggesting that these parameters expressed the strongest differences between the species.

Contrary to the hypothesis, the volume of knotless wood did not differ significantly between Scots pine and the provenances of lodgepole pine (Tab. 1), though, the VKN was significantly lower in Scots pine compared with the Summit lake provenance of lodgepole pine. The proportion of VKN differed significantly between the species and provenances; it was the lowest for Scots pine ( $\sim 9 \%)$ and the highest for the Fort Nelson provenance of lodgepole pine ( $14 \%)$. Additionally, dif- 
ferent proportions of VKN along stem axis were evident between the provenances of lodgepole pine and Scots pine (Fig. 5). The Fort Nelson provenance of lodgepole pine showed similar proportions of VKN along stem axis since there were no significant differences between parts of the crown and dry branch zone of the stem. The Summit Lake provenance of lodgepole pine showed slight gradual decrease of the proportion of VKN moving upwards on the stem; however, the differences were significant only between the dry branch zone of stem and upper quarter (IV) of crown. Scots pine showed notably (nearly two fold) and significantly higher proportion of VKN in the dry branch zone of stem $(\sim 10 \%)$ compared to the living part of the crown $(\sim 5.5 \%)$, while the proportion of VKN within living parts of the crown was similar and had low variation. The number and cross-section area of branches (dry, living and total) and mean distance between whorls was significantly higher for Scots pine than for lodgepole pine and the total cross-section of living branches differed also between the provenances of lodgepole pine (Tab. 1). Species or provenance had low effect on diameter of branches; nevertheless, mean diameter of living branches was significantly higher for Scots pine compared to the Summit Lake provenance of lodgepole pine.

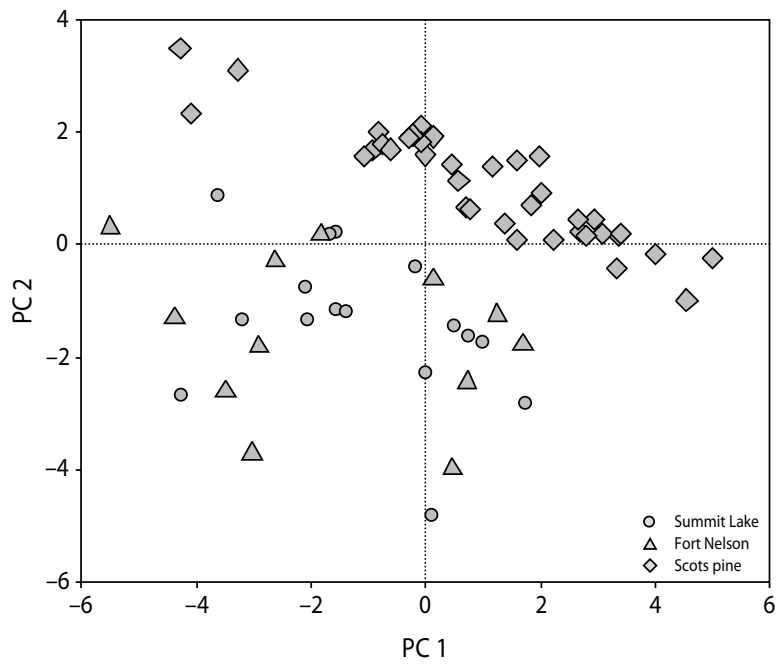

Figure 4. PCA ordination plot of sampled trees based on volume of woof occupied by knots and knotless volume, number of whorls and branch parameters (diameter, count and cross-section area). Two groups of trees of different species can be distinguished
A

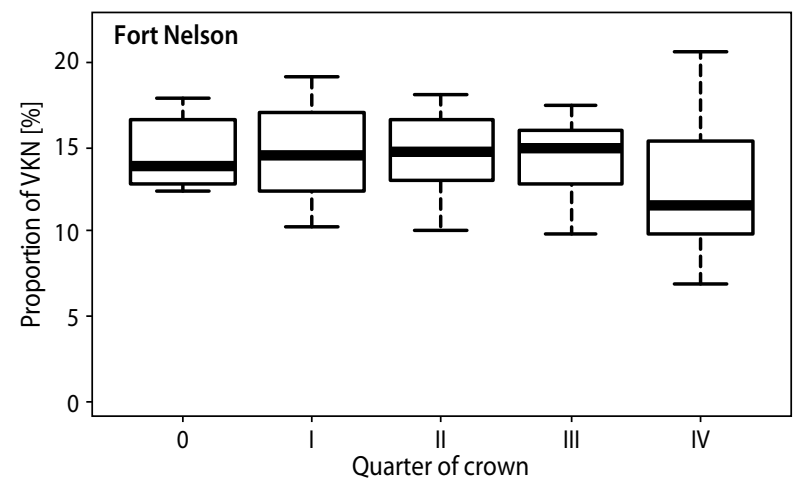

B

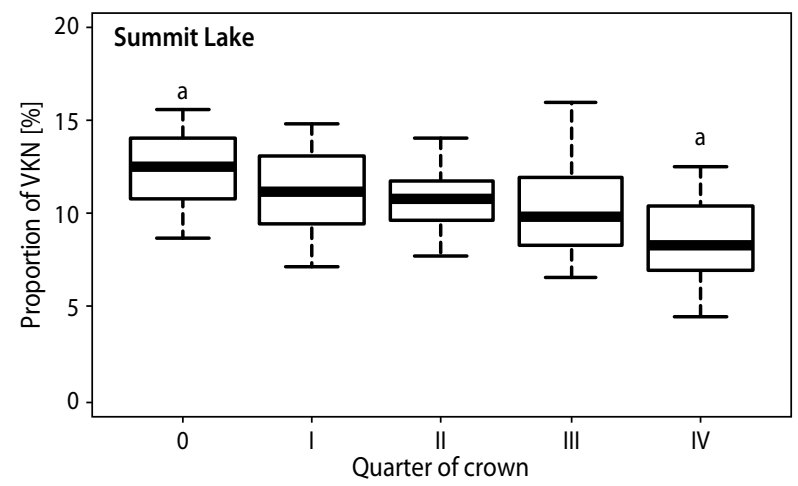

C

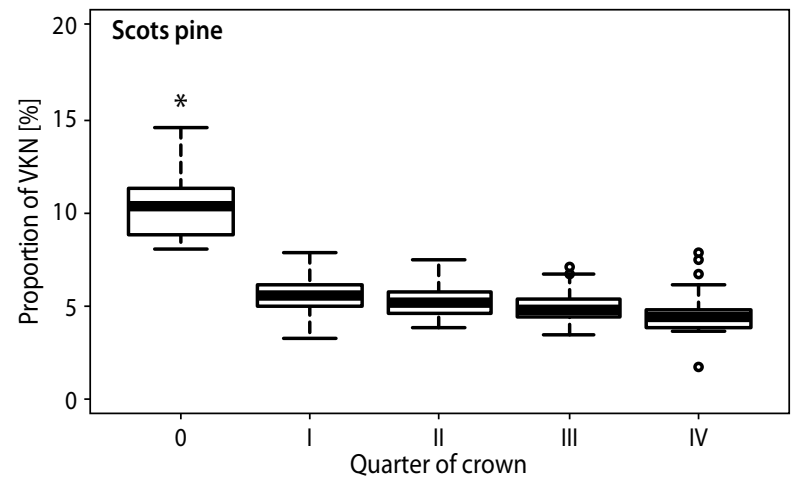

Figure 5. Proportion of volume of wood occupied by knots (VKN) in dry branch part of stem (0) and four quarters (IIV) of crown (living branch part of stem) of two provenances of lodgepole pine: A - Fort Nelson, B - Summit Lake and C - Scots pine. Letters indicate significant differences ( $p$-value $<0.05$ ) between specific pairs; asterisks- indicate significant differences $(p$-value $<0.05)$ from other groups (significance of differences determined by Tukey's HSD test) 
Table 1. Differences in volume and proportion of wood occupied by knots, volume of knotless wood and branch parameters (number, mean diameter and total cross-section) between two provenances (Fort Nelson and Summit Lake) of Lodgepole pine and Scots pine; $p$-values were calculated in ANOVA. Asterisks indicate the significance of differences from other two groups, letters indicate significant differences between specific pairs (according to Tukey's HSD test, $\alpha=0.05$ )

\begin{tabular}{|c|c|c|c|c|}
\hline & $\begin{array}{c}\text { Fort } \\
\text { Nelson }\end{array}$ & $\begin{array}{l}\text { Summit } \\
\text { Lake }\end{array}$ & $\begin{array}{l}\text { Scots } \\
\text { pine }\end{array}$ & $p$-value \\
\hline Number of trees & 20 & 24 & 42 & \\
\hline Mean VKN $\left(\mathrm{cm}^{3}\right)$ & 6439 & $7081 \mathrm{a}$ & $4265 a$ & $<0.01$ \\
\hline $\begin{array}{l}\text { Mean volume of } \\
\text { knotless stemwood } \\
\left(\mathrm{cm}^{3}\right)\end{array}$ & 38249 & 52719 & 41934 & 0.13 \\
\hline $\begin{array}{l}\text { Proportion of VKN } \\
(\%)\end{array}$ & 13.8 & 11.3 & 9.0 & $<0.01$ \\
\hline $\begin{array}{l}\text { Mean number of } \\
\text { whorls }\end{array}$ & 41.65 & 40.08 & $21.71^{*}$ & $<0.01$ \\
\hline $\begin{array}{l}\text { Mean distance } \\
\text { between whorls }(\mathrm{m})\end{array}$ & 0.28 & 0.23 & 0.48 & $<0.01$ \\
\hline $\begin{array}{l}\text { Mean number of } \\
\text { branches }\end{array}$ & 163.42 & 161.25 & $114.83^{*}$ & $<0.01$ \\
\hline $\begin{array}{l}\text { Mean number of dry } \\
\text { branches }\end{array}$ & 74.92 & $84.18 \mathrm{a}$ & $68.09 \mathrm{a}$ & $<0.01$ \\
\hline $\begin{array}{l}\text { Mean number of } \\
\text { living branches }\end{array}$ & 88.5 & 77.06 & $46.73^{*}$ & $<0.01$ \\
\hline $\begin{array}{l}\text { Mean diameter of } \\
\text { branches }(\mathrm{cm})\end{array}$ & 13.46 & 12.79 & 12.83 & 0.67 \\
\hline $\begin{array}{l}\text { Mean diameter of } \\
\text { dry branch }(\mathrm{cm})\end{array}$ & 13.55 & 12.70 & 11.77 & 0.06 \\
\hline $\begin{array}{l}\text { Mean diameter of } \\
\text { living branch }(\mathrm{cm})\end{array}$ & 14.21 & $13.27 \mathrm{a}$ & $15.28 \mathrm{a}$ & 0.05 \\
\hline $\begin{array}{l}\text { Total cross-section } \\
\text { of branches }\left(\mathrm{cm}^{2}\right)\end{array}$ & 37453 & 32958 & $23981^{*}$ & $<0.01$ \\
\hline $\begin{array}{l}\text { Total cross-section } \\
\text { of dry branches } \\
\left(\mathrm{cm}^{2}\right)\end{array}$ & 15803 & 16115 & $11587^{*}$ & $<0.01$ \\
\hline $\begin{array}{l}\text { Total cross-section } \\
\text { of living branches } \\
\left(\mathrm{cm}^{2}\right)\end{array}$ & $21650^{*}$ & 16842 & 12393 & $<0.01$ \\
\hline $\begin{array}{l}\text { Mean diameter } \\
\text { of three thickest } \\
\text { branches }(\mathrm{cm})\end{array}$ & 14.86 & 14.24 & 15.31 & 0.38 \\
\hline
\end{tabular}

Significant and tight relationships between VKN and morphometric parameters of trees were shown by Pearson correlation analysis (Tab. 2); however, these re- lationships differed between the provenances of lodgepole pine and Scots pine, suggesting different linkages of morphometric parameters of the trees and VKN as suggested by the PCA (Fig. 4). Volume of wood occupied by knots correlated significantly with stem diameter, tree height, cross-section area and diameter of branches (total and living) in both provenances of lodgepole pine and Scots pine (Tab. 2). Factors showing the highest correlation with VKN differed between proxies; total cross-section of branches showed strongest correlation in case of Scots pine and Fort Nelson provenance of lodgepole pine ( $r=0.89$ and 0.87 , respectively), stem diameter showed tightest correlation for the Summit lake provenance of lodgepole pine $(\mathrm{r}=0.95)$. Correlation coefficients between the proportion of VKN and morphometric parameters were overall lower than observed for VKN. The proportion of VKN of lodgepole pine correlated significantly with the number of whorls and additionally with stem diameter in case of both Summit Lake provenance. Proportion of VKN of Scots pine correlated significantly with diameter of branches for Scots pine; however, correlations were weaker (total mean diameter of living branches showed highest correlation coefficient of $r=0.44$ ). Total number of branches and number of dry branches did not show significant relationship with VKN or its proportion for any provenances or species.

\section{Discussion AND CONCLUSIONS}

In the studied trials, lodgepole pine trees from Summit Lake provenance were the most productive as their total height was significantly larger (Fig. 2) while diameter was similar to Scots pine and Fort Nelson provenance. In the Baltic Sea region, lodgepole pine has been previously shown to exceed Scots pine in biomass production (volume growth) at young and middle age (Elfving et al. 2001; Jansons et al. 2013). However, the Fort Nelson provenance of lodgepole pine showed the smallest tree height (Fig. 2), indicating the lowest productivity amongst the studied provenances. This suggests that higher wood (biomass) productivity of stand might be gained by the use of lodgepole pine from the appropriate provenance, as observed by trials in Sweden (Elfving and Norgren 1993). However, the advantage of lodgepole pine over Scots pine can 
Table 2. Pearson correlation coefficients between volume (VKN) and proportion of wood (\% VKN) occupied by knots and tree dimensions, branch count, diameter and cross-section of sampled trees of two provenances of lodgepole pine (Fort Nelson and Summit Lake) and Scots pine (df - degree of freedom for correlation analysis). Significant correlations are in bold (significance codes, $p$-values: $*<0.05, * *<0.01, * * *<0.001)$

\begin{tabular}{|l|c|c|c|c|c|c|c|c|c|}
\hline \multirow{2}{*}{} & \multicolumn{3}{|c|}{ Fort Nelson } & \multicolumn{3}{c|}{ Summit Lake } & \multicolumn{3}{c|}{ Scots pine } \\
\cline { 2 - 10 } & VKN & $\%$ VKN & df & VKN & $\%$ VKN & df & VKN & $\%$ VKN & df \\
\hline Stem diameter & $0.53^{*}$ & 0.24 & 18 & $0.95^{* *}$ & $0.55^{* *}$ & 22 & $0.84^{* * *}$ & $0.32^{*}$ & 40 \\
\hline Tree height & $0.71^{* * *}$ & -0.07 & 18 & $0.63^{* * *}$ & 0.03 & 22 & $0.64^{* * *}$ & -0.25 & 36 \\
\hline Number of whorls & 0.35 & $0.45^{*}$ & 18 & 0.25 & $0.68^{* * *}$ & 22 & $0.34^{*}$ & 0.26 & 40 \\
\hline Mean distance between whorls & 0.31 & 0.44 & 18 & -0.22 & $-0.50^{*}$ & 22 & $0.57^{* * *}$ & $-0.39^{*}$ & 40 \\
\hline Number of branches & 0.50 & 0.47 & 10 & 0.34 & $0.57^{*}$ & 14 & 0.16 & -0.08 & 40 \\
\hline Number of dry branches & 0.25 & 0.48 & 10 & -0.38 & 0.2 & 14 & 0.01 & -0.10 & 40 \\
\hline Number of living branches & 0.48 & 0.15 & 10 & $0.65^{* *}$ & 0.49 & 14 & 0.23 & 0.02 & 40 \\
\hline Mean branch diameter & $0.62^{*}$ & 0.08 & 10 & $0.50^{*}$ & -0.04 & 14 & $0.79^{* * *}$ & $0.31^{*}$ & 40 \\
\hline Mean diameter of dry branch & 0.45 & -0.02 & 10 & 0.38 & 0.01 & 14 & $0.65^{* * *}$ & 0.2 & 40 \\
\hline Mean diameter of living branch & $0.75^{* *}$ & 0.25 & 10 & $0.55^{*}$ & 0.04 & 14 & $0.84^{* * *}$ & $0.44^{* *}$ & 40 \\
\hline Total cross-section of branches & $0.87^{* * *}$ & 0.36 & 10 & $0.79^{* * *}$ & 0.22 & 14 & $0.89^{* * *}$ & $0.37^{*}$ & 40 \\
\hline Total cross-section of dry branches & $0.66^{*}$ & 0.38 & 10 & 0.15 & 0.07 & 14 & $0.79^{* * *}$ & 0.28 & 40 \\
\hline Total cross-section of living branches & $0.81^{* *}$ & 0.28 & 10 & $0.78^{* * *}$ & 0.20 & 14 & $0.81^{* * *}$ & $0.37^{*}$ & 40 \\
\hline Mean diameter of three thickest branches & $0.71^{* *}$ & 0.18 & 10 & $0.57^{*}$ & -0.10 & 14 & $0.85^{* * *}$ & $0.33^{*}$ & 40 \\
\hline
\end{tabular}

be debated. Although the volume of knotless wood did not differ significantly between lodgepole pine and Scots pine, the distance between whorls was two times higher for Scots pine (Tab. 1). This implies that longer solid knotless details can be made from Scots pine; however, lodgepole pine had larger volume of knotless wood, suggesting that a higher number of smaller details might be produced. Thus, the higher productivity of lodgepole pine appears to be countervailed by increased knottiness of stemwood. The proportion of VKN differed significantly between Scots pine and lodgepole pine (Tab. 1), suggesting that the volume of leftovers (VKN) in production of knotless wood will apparently be higher if the timber of lodgepole pine is used. The angle of branches, which is used as a parameter for selection of the best traits of trees (Mäkinen and Colin 1998), was apparently not efficient in comparisons of knotless wood volume of Scots pine and lodgepole pine. Lodgepole pine had two times more whorls than Scots pine (Tab. 1), but the branch angles were quite similar (Fig. 3), thus higher VKN in lodgepole might be explained by whorl number.
Scots pine and lodgepole pine had diverse branch traits as shown by ANOVA (Tab. 1) and PCA (Fig. 4) of branch parameters. The ordination of trees showed that the main differences in branch traits were observed between species, as they had distinct grouping of trees. This might be easily explained by differences in species biology, as lodgepole normally forms several whorls per year, while Scots pine only one (Białobok 1975; Koch 1996). Branch traits of studied provenances of lodgepole pine were rather similar, judging by PCA, as both provenances were randomly distributed within the same group (Fig. 4). Apparently, both provenances of lodgepole pine differed mainly due to dimensions of stem (Fig. 2), rather than branch parameters. Nevertheless, Fort Nelson provenance apparently allocated more resources in branch growth as it had the highest cross-section of living branches (Tab. 1). This suggests that the morphometric parameters might be used to identify the most sufficient lodgepole or selection of the most appropriate management (Mäkinen and Colin 1998). Nevertheless, diversity of sets of significant correlations between VKN and morphometric parameters (Tab. 2) suggests that selection 
parameters should be considered separately for each species or provenance. The proportion of VKN of lodgepole pine showed the strongest relationship with number of whorls; however, diameter of branches had the strongest effect on the proportion of VKN for Scots pine. Apparently these two parameters are countervailed to maintain the optimum leaf area (Honda and Fisher 1978; Weiskittel et al. 2009). Higher VKN was related with increased cross-section of branches, which is representative for the number and diameter of branches and apparently is better predictor of VKN than the number of branches or whorls alone. The high correlation between VKN and diameter observed for Summit Lake provenance of lodgepole pine (Tab. 2) might be explained by higher variability of diameter (Fig. 2).

Lodgepole pine from Summit Lake provenance showed higher productivity compared to Scots pine in experimental plantation in central part of Latvia at the age of 28 years. However, the volume of knotless stemwood was similar between both species, which might be explained by the differences in productivity and branch traits. Lodgepole pine formed twice as much whorls compared to Scots pine, the branches were smaller and branch angles were wider. Accordingly, the proportion of wood occupied by knots was significantly higher for lodgepole pine compared to Scots pine (11.3 and $9.0 \%$, respectively). Considering higher productivity and knottiness of stemwood, lodgepole pine might have high potential for biomass production. The amount of VKN can be predicted by morphometric parameters of trees; however, these predictors appear specific for species and provenance, suggesting that branch traits might slightly differ between provenances of lodgepole pine.

\section{Acknowledgements}

Collection of the material and data analysis was funded by ESF project «Importance of Genetic Factors in Formation of Forest Stands with High Adaptability and Qualitative Wood Properties» (No. 2009/0200/1DP/1.1.1.2.0/09/APIA/VIAA/146) and Forest Competence Centre (ERAF) project «Methods and technologies for increasing forest capital value» (No. L-KC-11-0004). We also acknowledge Andis Adamovičs, Endijs Bāders and Raitis Rieksts-Riekstins for help during the collection of material.

\section{References}

Baumanis I., Birǵelis J., Paegle M. 1992. How promising for Latvia is lodgepole pine (Pinus contorta Dougl. var. latifolia Engelm.). Mežzinātne, 1, 4-14 (in Latvian with English abstract).

Baumanis I., Jansons Ā., Gaile A. 2006. Inventorying and creating a database for long-term trial plots in forest research. Mežzinātne, 16, 102-112 (in Latvian with English abstract).

Białobok S. 1975. Scots pine - Pinus sylvestris L. Foreign Service Publications Department, Washington.

Burton L. 2012. Introduction to forestry science, 3rd edition. Cengage Learning, New York.

Bušs K. 1976. Basis of Forest classification in Latvia SSR. LRZTIPI, Rīga (in Latvian).

Cieszewski C.J., Bella I.E. 1989. Polymorphic height and site index curves for lodgepole pine in Alberta. Canadian Journal of Forest Research, 19, 1151-1160.

Elfving B., Ericsson T., Rosvall O. 2001. The introduction of lodgepole pine for wood production in Sweden-a review. Forest Ecology and Management, 141, 15-29.

Elfving B., Norgren O. 1993. Volume yield superiority of lodgepole pine compared to Scots pine in Sweden. In: Proceedings of IUFRO meeting and Frans Kempe Symposium 1992 on Pinus contorta provenances and breeding, 69-80.

Gallagher G.J., Lynch T.J., Fitzsimons B. 1987. Lodgepole pine in the Republic of Ireland II. Yield and management of coastal lodgepole pine. Forest Ecology and Management, 22, 185-203.

Honda H., Fisher B. 1978. Tree branch angle: maximizing effective leaf area. Science, 199, 888-890.

Jansons A., Matisons R., Lībiete-Zālīte Z., Baders E., Rieksts-Riekstiņš J. 2013. Relationships of height growth of lodgepole pine (Pinus contorta var. latifolia) and Scots pine (Pinus sylvestris) with climatic factors in Zvirgzde, Latvia. Baltic Forestry, 19, 236-244.

Jansons A., Sisenis L., Neimane U., Rieksts-Riekstins J. 2013. Biomass production of young lodgepole pine (Pinus contorta var. latifolia) stands in Latvia. Forest, 6, 10-14.

Kärkkäinen L., Matala J., Härkönen K., Kellomäki S., Nuutinen S. 2008. Potential recovery of industrial 
wood and energy wood raw material in different cutting and climate scenarios for Finland. Biomass and Bioenergy, 32, 934-943.

Koch P. 1996. Lodgepole pine in North America. Forest Products Society, Washington.

Larsen J.B. 1980. Older provenance trials with Pinus contorta in Denmark. Pinus contorta as an Exotic Species. In: Proceedings of IUFRO meeting 1980 on Pinus contorta provenances in Norway and Sweden, 45-58.

Lindelöw A., Björkman C. 2001. Insects on lodgepole pine in Sweden-current knowledge and potential risks. Forest Ecology and Management, 141, 107-116.

Lines R. 1996. Experiments on lodgepole pine seed origins in Britain. Technical paper 10. Forestry Commission, Edinburgh.

Mäkinen H., Colin F. 1998. Predicting branch angle and branch diameter of Scots pine from usual tree measurements and stand structural information. Canadian Journal of Forest Research, 28, 1686-1696.

Mauriņš A., Zvirgzds A. 2006. Dendrology. Latvijas Universitātes apgāds, Rīga (in Latvian).

Oksanen J., Blanchet F.G., Kindt R., Legendre P., Minchi P.R., O’Hara R.B., Simpson G.L., Solymos P., Stevens M.H., Wagner H. 2013. Vegan: Community Ecology Package. R package version 2.0-6. http://CRAN.R-project.org/package=vegan.

Persson A. 1993. Wood properties of Pinus contorta. In: Proceedings of IUFRO meeting and Frans Kempe Symposium 1992 on Pinus contorta provenances and breeding, 38-59.

Pfister R.D., Daubenmire R. 1975. Ecology of Lodgepole pine Pinus contorta Dougl. In: Management of lodgepole pine ecosystems (ed.: D.M. Baumgartner). Washington State University, Pullman, 27-46.

R Core Team 2014. R: A language and environment for statistical computing. R Foundation for Statistical
Computing, Vienna, Austria. URL http://www.Rproject.org/.

Sable I., Grinfelds U., Jansons A., Vikele L., Irbe I., Verovkins A., Treimanis A. 2012. Comparison of the properties of wood and pulp fibbers from lodgepole pine (Pinus contorta) and Scots pine (Pinus sylvestris). BioResources, 7, 1771-1783.

Sauter U.H. 1997. Potential of small dimensioned, low quality round wood of Scots pine for the production of valuable timber. In: Role of wood production in ecosystem management. Proc. of the Sustainable Forestry Working Group at the IUFRO (eds.: R.J. Barbour, K.E. Skog), 59-66.

Savill P., Evans J., Auclair D., Falck J. 1997. Plantation silviculture in Europe. Oxford University Press, New York.

Shmulsky R., Jones P.D. 2011. Forest products and wood science. John Wiley and Sons, New York.

Sokal R.R., Rohlf F.J. 1995. Biometry, 3rd ed. Freeman and Company, New York.

Weiskittel A.R., Kershaw J.A., Hofmeyer P.V., Seymour R.S. 2009. Species differences in total and vertical distribution of branch- and tree-level leaf area for the five primary conifer species in Maine, USA. Forest Ecology and Management, 258, 1695-1703.

Wheeler N.C., Critchfield W.B. 1985. The distribution and botanical characteristics of lodgepole pine: biogeographical and management implications. In: Lodgepole pine, the species and its management (ed.: D.M. Baumgartner et al.). Washington State University, Pullman, 1-13.

Whiteman A., Brown C. 1999. The potential role of forest plantations in meeting future demands for industrial wood products. International Forestry Review, 1, 143-152.

Žiogas A., Juronis V., Sneškiene V., Gabrilavičius R. 2006. Pathological condition of introduced conifers in the forests of South-Western and Western Lithuania. Baltic Forestry, 12, 234-242. 